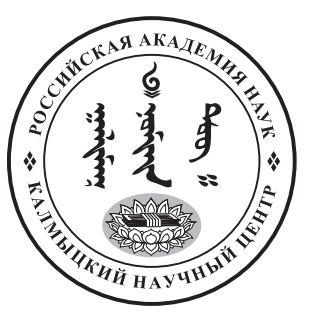

Published in the Russian Federation

Oriental Studies (Previous Name: Bulletin of the Kalmyk Institute

for Humanities of the Russian Academy of Sciences)

Has been issued as a journal since 2008

ISSN: 2619-0990; E-ISSN: 2619-1008

Vol. 14, Is. 1, pp. 24-32, 2021

Journal homepage: https://kigiran.elpub.ru

УДК / UDC 94(47)

DOI: $10.22162 / 2619-0990-2021-53-1-24-32$

\title{
Калмыцко-казахское противостояние в Северном Прикаспии в 1723-1724 гг.
}

\section{Владимир Толтаевич Тепкеев ${ }^{1}$}

${ }^{1}$ Калмыцкий научный центр РАН (д. 8, ул. им. И. К. Илишкина, 358000 Элиста, Российская Федерация)

кандидат исторических наук, ведущий научный сотрудник

iD 0000-0002-4140-8358. E-mail: tvt75@mail.ru

(C) КалмНЦ РАН, 2021

(C) Тепкеев В. Т., 2021

Аннотация. Введение. Статья посвящена одной из малоизвестных страниц в истории Калмыцкого ханства — началу вооруженного противостояния казахов и каракалпаков с калмыцкими отрядами в 1723-1724 гг. Цель статьи - введение в научный оборот новых архивных сведений о периоде правления калмыцкого хана Церен-Дондука (1724-1735 гг.). Материаль и методы. Источниковой базой послужили материалы Национального архива Республики Калмыкия, хранящиеся в фонде И-36. В «Журнале по калмыцким делам» отложились донесения и рапорты астраханского губернатора А. П. Волынского «О происходивших между калмыцкими владельцами ссорах и междоусобиях». При работе с архивным материалом применялся историко-сравнительный метод, с помощью которого автор сопоставил хронику событий на основе совпадающих сведений, содержащихся во всех или в большинстве источников. Резульmaты. Начавшаяся калмыцкая междоусобица среди молодых владельцев за передел улусов в 1723 г., смерть хана Аюки в 1724 г. и неурегулированный вопрос о престолонаследии в ханстве создали условия для набегов казахов и каракалпаков на восточные окраины Калмыцкого ханства, расположенные в волго-яицком междуречье. Bыводы. В условиях политической раздробленности в Калмыцком ханстве владельцы восточных улусов во главе с Дорджи Назаровым сумели оказать вооруженный отпор противнику. Узенинское сражение 1724 г. имело важные военные и политические последствия, поскольку разгром небольшого отряда казахов и каракалпаков показал, что захват калмыцких земель, даже в условиях отсутствия единства среди калмыцкой знати, является весьма нелегким делом. Однако этот небольшой локальный успех волжских калмыков не мог остановить дальнейшую экспансию казахов в восточном направлении.

Ключевые слова: Калмыцкое ханство, калмыки, казахи, каракалпаки, Артемий Волынский, Дорджи Назаров, русско-калмыцкие отношения

Благодарность. Исследование проведено в рамках государственной субсидии - проект «Комплексное исследование процессов общественно-политического и культурного развития народов Юга России» (номер госрегистрации: АААA-А19-119011490038-5). 
Для цитирования: Тепкеев В. Т. Калмыцко-казахское противостояние в Северном Прикаспии в 1723-1724 гг. // Oriental Studies. 2021. Т. 14. № 1. С. 24-32. DOI: 10.22162/2619-0990-202153-1-24-32

\title{
The Northern Caspian, 1723-1724: Kalmyk-Kazakh Confrontation
}

\author{
Vladimir T. Tepkeev ${ }^{1}$
}

${ }^{1}$ Kalmyk Scientific Center of the RAS (8, Ilishkin St., Elista, 358000, Russian Federation) Cand. Sc. (History), Leading Research Associate

iD 0000-0002-4140-8358. E-mail: tvt75@mail.ru

\author{
(C) KalmSC RAS, 2021 \\ (C) Tepkeev V. T., 2021
}

\begin{abstract}
Introduction. The paper examines an understudied period in the history of the Kalmyk Khanate - beginnings of a military confrontation between joint Kazakh-Karakalpak forces and Kalmyk units in 1723-1724. Goals. The article aims at introducing newly discovered archival data about the reign of Khan Tseren-Donduk (1724-1735). Materials and Methods. The source materials are related records stored at the National Archive of Kalmykia (Coll. И-36). The Register of Kalmyk Affairs contains dispatches and reports by the Governor of Astrakhan, A. Volynsky, clustered under the title 'About Actual Disagreements and Feuds of Kalmyk Landlords'. The employed historical comparative method makes it possible to specify a chronicle of events on the basis of coinciding events described by all or most of the investigated sources. Results. The 1723 feuds between young Kalmyk princely heirs, Khan Ayuka's death in 1724, and the unsettled order of succession paved the path for Kazakh and Karakalpak invasions of eastern Kalmyk-inhabited territories between the Volga and the Yaik (Ural) Rivers. Conclusions. Despite the actual political factionalism across the Kalmyk Khanate, eastern landlords headed by Dorji Nazarov were able to repel the aggression of hostile groups. The 1724 battle of the Uzen which ended in a defeat of a small Kazakh-Karakalpak unit had important military and political consequences conveying the message that even amidst the lack of solidarity between Kalmyk noblemen any invasion of their lands should turn an essentially arduous task. However, the successful local engagement of the Volga Kalmyks could not stop the subsequent eastward expansion of Kazakhs.
\end{abstract}

Keywords: Kalmyk Khanate, Kalmyks, Kazakhs, Karakalpaks, Artemy Volynsky, Dorji Nazarov, Russian-Kalmyk relations

Acknowledgements. The reported study was funded by government subsidy — project name 'SocioPolitical and Cultural Development of South Russia's Peoples: Comprehensive Studies of Respective Processes' (state reg. no. AAAA-A19-119011490038-5).

For citation: Tepkeev V. T. The Northern Caspian, 1723-1724: Kalmyk-Kazakh Confrontation. Oriental Studies. 2021. Vol. 14(1): 24-32. (In Russ.). DOI: 10.22162/2619-0990-2021-53-1-24-32

\section{है}

\section{Введение}

История калмыцко-казахских отношений в XVIII в. еще не была темой отдельного большого исследования, хотя в историографии есть ряд публикаций, затрагивающих отдельные проблемы этого вопроса [Бобров 2013; Болдырева 2017; Кундакбаева 2005; Сабитов 2014; Тепкеев 2019; Торо- пицын, Сусеева, Кундакбаева 2019; Цюрюмов 2009].

В отличие от истории джунгаро-казахских отношений данная тема также требует более тщательного и внимательного исследования с привлечением новых архивных данных. История непростых взаимоотношений двух кочевых народов в XVIII в. затра- 
гивала разные политические проблемы, в решении которых в первую очередь принимало участие Российское государство.

\section{Постановка задачи}

На основе архивных материалов в статье вводятся в научный оборот новые сведения о калмыцко-казахском противостоянии в 1723-1724 г., серьезно повлиявшем на положение в Северном Прикаспии.

\section{Материалы и методы}

Источниковой базой к статье послужили материалы Национального архива Республики Калмыкия, хранящиеся в фонде И-36 «Состоящий при калмыцких делах при астраханском губернаторе». В «Журнале по калмыцким делам» отложились донесения и рапорты астраханского губернатора Артемия Петровича Волынского и его помощников, а конкретно - дело «О происходивших между калмыцкими владельцами ссорах и междоусобиях» [НА РК. Ф. И-36. Оп. 1. Д. 15].

Отдельные документы были опубликованы в «Материалах по истории каракалпаков» [Материалы 1935] и «Истории Казахстана в русских источниках XVI-XX вв.» [История Казахстана 2005]. Достоверность представленных архивных сведений проверялась путем выявления их происхождения, сравнения и сопоставления с другими источниками, содержащими похожую информацию.

\section{Первые столкновения калмыков казахами в 1723 - начале 1724 гг.}

В конце зимы - начале весны 1724 г. восточные калмыцкие кочевья подверглись внезапному вторжению казахско-каракалпакского войска во главе с Абулхаиром. Стоит отметить, что кочевья калмыков подверглись нападению казахов еще в 1723 г., и калмыцкие владельцы, разрозненные и участвовавшие в борьбе за власть, не имели пока возможности участвовать в новой войне [Бобров 2013: 6-7]. Попытка калмыцкой стороны летом 1723 г. урегулировать проблему мирным путем закончилась провалом, поскольку казахский правитель Абулхаир прямо заявил калмыцким представителям о своей готовности к войне, подтвердив свою решимость убийством трех и пленением семерых посланников [История Казахстана 2005: 308].
Столь агрессивное поведение казахского правителя по отношению к волжским калмыкам можно объяснить лишь последствием мощного вторжения джунгарских войск в Восточный и Юго-Восточный Казахстан в начале 1720-х гг., в результате которого пострадало большое количество казахов, киргизов и каракалпаков. Удар джунгаров практически расколол на две части казахские жузы: одна часть казахов отступила в южном направлении к среднеазиатским городам, другая часть казахов и каракалпаков отступила в западном направлении, непосредственно войдя в соприкосновение с восточными окраинами калмыцких кочевий. Этот период стал известен в истории казахского народа как «Время великого бедствия» («Актабан шубырынды»). И хотя волжские калмыки не имели прямого отношения к этим событиям, джунгары в очередной раз запустили древний механизм «переселения народов». На этот раз роль переселенцев выпала на долю казахов и каракалпаков, а объектом вторжения стали восточные кочевья калмыков [Бобров 2013: 6]. Традиционно владение Дорджи Назарова находилось в волго-яицком междуречье и выполняло роль заслона с восточного направления и в целом отвечало за казахское направление [Батмаев 1993: 117].

В Царицыне 20 марта были получены сведения от дворянина Якова Татаринова, ранее отправленного в улус Дорджи Назарова, который кочевал от Саратова к югу в 60 верстах, в верховьях реки Тарлык. На месте Я. Татаринов и узнал от Д. Назарова о набеге 13-тысячного казахско-каракалпакского войска султана Абулхаира [НА РК. Ф. И-36. ОП. 1. Д. 17. Л. 102]. По сведениям Дорджи Назарова, казахам и каракалпакам удалось взять в полон 50 калмыков, 500 верблюдов и 8 тыс. овец. Другие калмыцкие владения, кочевавшие по соседству, потеряли 400 человек пленными, 600 верблюдов, 3 тыс. голов крупного скота и 10 тыс. овец. Кочевье напавшей стороны располагалось в верховьях реки Эмбы. В боевом столкновении калмыкам удалось уничтожить 40 каракалпаков и 15 человек взять в плен. Один из каракалпакских пленных сообщил, что в войске казахского султана Абулхаира находилось до 10 тыс. каракалпаков [НА РК. Ф. И-36. Оп. 1. Д. 17. Л. 102, 102об.]. 
Усиливавшийся натиск противника с восточного направления толкал Дорджи Назарова с улусом не только прижиматься к Волге, но и думать о переходе на правый берег, где располагались практически все калмыцкие улусы. В силу сохранявшейся возможности нового нападения каракалпаков калмыцкий владелец просил российские власти перевести его улус через Волгу в районе Саратова. Как вариант он рассматривал и возможность присылки к нему русского отряда численностью в две тысячи драгун, а также шести пушек [НА РК. Ф. И-36. Оп. 1. Д. 17. Л. 1020б.].

20 марта из Саратова Шахматов передавал, что к нему прибыл посланец Дорджи Назарова с письмом, в котором владелец просил разрешения отправить его четырех людей во главе с Самтаном и пленным каракалпаком в Москву. Далее в письме он пишет: «Касаки и каракалпаки, десять тысяч человек, приходили и с нами бились боем, и те ведомости предлагать посылаю Его Императорскому величеству своих посланцов» [НА РК. Ф. И-36. Оп. 1. Д. 17. Л. 133-133об.]. Словесно Самтан передал Шахматову более уточненные данные: потери калмыков от нападения противника составили 60 человек убитыми, 500 верблюдов и 6 тыс. овец [НА РК. Ф. И-36. Оп. 1. Д. 17. Л. 133-133об.].

2 апреля Самтан встретился с В. П. Беклемишевым в Грачевской крепости на линии, и тот разрешил калмыцким посланцам выехать из Саратова в Москву в счет казны. Саратовский комендант Г. Н. Репьев получил указание всячески содействовать Дорджи Назарову по переводу его калмыков через Волгу на правый берег [Пальмов 1929: 213].

12 июня Дорджи Назаров письменно сообщал, что ханские посланцы во главе с Цойриши, которые осенью 1723 г. были отправлены к мангышлакским туркменам для сбора дани, на обратном пути подверглись нападению со стороны «воровских» казахов и были разбиты [НА РК. Ф. И-36. Оп. 1. Д. 18. Л. 263].

Наступление казахов и каракалпаков Боевые действия продолжились и летом 1724 г. 30 июля к Р. С. Тургеневу и В. П. Беклемишеву в Саратов прибыл человек Дорджи Назарова с письмом, в котором владелец сообщал о тревожных новостях, связанных с захватом его людей и скота в пограничных улусах. Его разведка за Яиком, в районе реки Якшибай, обнаружила следы и огни движения многочисленного неприятеля. Чтобы предупредить о надвигающейся угрозе, калмыцкие разведчики в течение пяти суток преодолели обратный путь, на который ранее потратили 15 дней. С целью защитить свои владения с восточного направления Дорджи Назаров срочно с войском последовал в приграничные улусы, которые уже на тот момент потеряли 20 человек, 15 верблюдов и 100 лошадей [НА РК. Ф. И-36. Оп. 1. Д. 18. Л. 80]. По показаниям пленного каракалпака Апана Байсарова, набег на улус Лубжи совершил казахско-каракалпакский отряд из двухсот человек под командой Есета Кулубая. В районе реки Кунчулук, на правобережье Яика, они разгромили одно из калмыцких селений [НА РК. Ф. И-36. Оп. 1. Д. 19. Л. 102].

Посланник Дорджи Назарова, Хасай, уже устно дополнил письменные сведения, пояснив губернатору А. Волынскому мнение своего владельца, которое сводилось к тому, что неприятель был в курсе о начавшейся внутрикалмыцкой междоусобице. Поэтому неприятель, собрав большое войско, двинулся на калмыков, чтобы окончательно разорить улус Дорджи Назарова. Теснимые с востока джунгарами, казахи и каракалпаки пытались компенсировать свои материальные потери за счет волжских калмыков. По мнению Хасая, «каракалпаки и киргис касаки на лошадях битца плохи, а пеши крепки» [НА РК. Ф. И-36. Оп. 1. Д. 18. Л. 80об.].

По мнению Н. Н. Пальмова, улусу Дорджи Назарова грозила несомненная опасность, и владельцу предстояло стать во главе улусного войска и приготовиться ко встрече с противником, отложив на время свой приезд в Саратов. Вместе с тем он не стремился искать более спокойного места при Волге [Пальмов 1929: 220]. Учитывая это обстоятельство, Дорджи Назаров, приказав улусам отступать к Волге, собрал 18-тысячную конницу и разделил ее на три колонны, выдвинув их навстречу противнику. В случае сильного наступления казахско-каракалпакского войска калмыцкий владелец предполагал отступление к Саратову, на помощь гарнизона которого 
он рассчитывал [НА РК. Ф. И-36. Оп. 1. Д. 18. Л. 80об.]. А. Волынский поддержал такой план Дорджи Назарова и заверил его в оказании военной помощи, тем более что по этому поводу имелся и государевый указ [НА РК. Ф. И-36. Оп. 1. Д. 15. Л. 418].

5 августа Дорджи Назаров снова письменно извещает астраханского губернатора в Саратове о движении казахов и каракалпаков за Яиком. На этот раз он получил сведения от своей разведки, что неприятель идет вниз по реке Якшибай и собирается перейти реку Яик ниже Яицкого городка. Две небольшие партии противника уже подбегали под калмыцкие улусы и увели в плен несколько людей и немного голов скота, но это, по всей видимости, были только разведывательные отряды. Дорджи Назаров с войском находился на границе и внимательно наблюдал за передвижениями противника [НА РК. Ф. И-36. Оп. 1. Д. 18. Л. 112].

20 августа в Саратов прибыл посланец Дорджи Назарова, Зубак, который ранее участвовал в разведывательном рейде. По словам Зубака, он в начале августа во главе сотни калмыков на левом берегу Яика внезапно столкнулся с небольшим отрядом каракалпаков, который в результате боя был полностью уничтожен. Захватив «языков», калмыки стали отступать, но, не доходя до Яика, были настигнуты основными силами каракалпакского войска. Потеряв одного человека пленным, Зубаку все-таки удалось скрыться от преследования противника. По показаниям пленных каракалпаков, захваченных еще при первом боевом столкновении, общее количество войска казахов и каракалпаков, участвовавших в набеге на калмыков, составляет 10 тыс. человек. Переход Яика они наметили выше Яицкого городка [НА РК. Ф. И-36. Оп. 1. Д. 19. Л. 73-73об.].

\section{Столкновения на Узени}

Один из помощников А. Волынского, Степан Шахматов, сообщал из улуса Дорджи Назарова, что в ночь на 21 августа казахи на реке Узени совершили нападение на улус Лубжи, сына владельца. Дорджи Назаров, запросив у астраханского губернатора военной помощи, во главе войска срочно выдвинулся в этот район, находившийся в волго-яицком междуречье. Особенно калмыцкий владелец просил прислать ему ар- тиллерию, поскольку рассчитывал догнать казахов и использовать ее при их осаде [НА РК. Ф. И-36. Оп. 1. Д. 19. Л. 89-89об.].

Как сообщал В. М. Бакунин, у астраханского губернатора в Саратове в распоряжении не было ни одной полковой пушки, только две роты драгун и 200 казаков [Бакунин 1995: 43]. Однако, чтобы не вызвать недовольство владельца, А. П. Волынский не мог открыто ему отказать и отправил к нему дворянина Якова Татаринова, чтобы тот на месте выяснил реальную угрозу со стороны казахов и каракалпаков, заверив калмыков в скором оказании военной помощи [НА РК. Ф. И-36. Оп. 1. Д. 15. Л. 80об.]. Имея на руках государевый указ защищать всеми силами Дорджи Назарова, губернатор просил правительство прислать дополнительно в Саратов 300 драгун и 500 донских казаков [НА РК. Ф. И-36. Оп. 1. Д. 19. Л. 97-97об.]. Понятно, что Дорджи Назарову пришлось надеяться только на свои собственные силы, поэтому ему пришлось мобилизовать все силы восточных улусов [История Калмыкии 2009: 386, 387].

24 августа С. Шахматов вернулся в Саратов в сопровождении Бабича, посланца Дорджи Назарова. От присланного калмыка стало известно, что Дорджи Назарову удалось на Узени настичь отряд каракалпаков, который насчитывал всего 750 человек, и с ходу их атаковать. Исход боя во многом решила привезенная калмыками артиллерия, в результате чего каракалпаки были полностью уничтожены, несколько человек попали в плен и только троим удалось вырваться из окружения. В качестве свидетельства одержанной победы Бабич привез одного пленного каракалпака и 415 правых ушей, «отрезанных от каракалпацких мертвых тел» [НА РК. Ф. И-36. Оп. 1. Д. 15. Л. 84об.85].

В работе В. М. Бакунина представлена более цельная картина сражения, составленная на основе свидетельств современников сражения: «... киргиз-касак на Лубжин улус нападало 757 человек, которых Лубжа с войсками своими, догнав, атаковал в урочище Узенях, куда и Доржи с войсками своими приспел, и, соединясь, их, киргисцов, доставали приступом и из пушек своих по ним стреляли, и так многих из них побили и несколько взяли живых, и только из них ушло три человека; и при том прислан к 
Волынскому в подарок один взятый киргискасак» [Бакунин 1995: 43].

Весьма интересны показания пленных казахов, взятых в различных боевых столкновениях с калмыками. Например, казах Атбай Туганов, из владения хана Среднего жуза Семеке, сообщал, что первым объектом их нападения был улус Лубжи, в результате чего ими было захвачено «несколько ясыря и скота». Однако на обратном пути они были настигнуты калмыками во главе с Лубжи и Лекбеем и полностью разбиты [История Казахстана 2005: 315-316].

Другой пленный казах, Каратай Сумергенев, подданный правителя Младшего жуза Абулхаира, предоставил более полные сведения. Согласно ему, отряд Есета Кулубая, который насчитывал около 500 человек, на правом берегу Яика соединился с отрядом из 200 каракалпаков. Затем они совместно выдвинулись и рано утром совершили набег на калмыцкий улус Лубжи. При отступлении были разбиты и взяты в плен калмыками [История Казахстана 2005: 316].

\section{После сражения}

В этот же день губернатор А. П. Волынский сразу же отправил к Дорджи Назарову С. Шахматова с поздравлением «с его счастливою победою, которую получил он над каракалпаками» [НА РК. Ф. И-36. Оп. 1. Д. 15. Л. 85].

В своем докладе в Сенат губернатор систематизировал разрозненные сведения калмыков и пленных о том сражении: «Августа 21-го числа на улусы ево, Дорджи Назарова, напали кайсаки и каракалпаки, с ними ж были и башкирцы, а всех было 757 человек. Объехав караулы их (калмыков), напали на них сонных и въехали в улусы сына Доржина Лубжи, который и сам с трудом спасся и ушел. Каракалпаки и прочие, побрав немалое число людей и скота, пошли назад. Лубжа, собрав войска и догнав неприятелей, разбил их в урочище Узени, отсюда в верстах в двухстах; [ушло только] три человека, а прочих калмыки всех побили и в полон побрали. Такой победы у калмык над каракалпаками никогда не бывало, [почему] в знак такой победы Доржа и дети ево послали ко мне в презент 12 человек полонянников да 415 человеческих ушей и четыре лошади каракалпацких» [История Казахстана 2005: 317].
На основе комплексного анализа вещественных, письменных и изобразительных источников Л. А. Бобров в своей работе дает информацию об особенностях вооружения и тактики калмыков, казахов и каракалпаков в Узенинском сражении 1724 г. [Бобров 2013]. Он отмечает, что, несмотря на преобладание численности каракалпаков в отряде Кулубая, они находились в подчинении у казахских правителей, и именно казахские командиры возглавляли такие объединенные воинские соединения. 57-летний Есет Кулубай, опытный военачальник, являлся главой рода тама поколения жетыру и входил в ближайший круг хана Абулхаира. Пытаясь повторить успешные военные набеги казахов 1723 - весны 1724 гг., он ставил перед собой конкретную цель разгромить улус Лубжи и в дальнейшем отступить на восток [Бобров 2013: 9]. Желание захватить и привести домой как можно больше живого ясыря и скота не давало возможности отряду Есета Кулубая быстро двигаться. Поэтому калмыкам не составило большого труда их настичь и блокировать на открытом пространстве в степи. Высокая мобильность калмыцких отрядов позволила им оперативно оказать помощь Лубжи [Бобров 2013: 12-13].

Письменные источники того времени показывают, что казахи и каракалпаки не смогли верно оценить свои возможности при организации набега на калмыцкий улус. Не желая бросать в степи трофеи, казахский командир принял решение организовать оборону и дать бой превосходящим силам калмыков. Это и стало главной причиной их полного разгрома. Калмыцкая сторона, наоборот, сумела оперативно сконцентрировать различные отряды на главном направлении удара. Нужно отдать должное и Лубжи, который, несмотря на то, что «проспал» нападение казахов, сумел тем не менее быстро мобилизовать все силы в единый кулак, догнать и блокировать противника. Ключевую роль в окончательном разгроме сыграла полевая артиллерия, доставленная к месту битвы Дорджи Назаровым. Узенинское сражение стало первой большой победой калмыков над казахами и каракалпаками с начала 1720-х гг. Особо стоит отметить, что военный успех калмыков был достигнут без поддержки российских войск [Бобров 2013: 14]. 


\section{Выводы \\ Влияние России на события в Север- ном Прикаспии}

В условиях политической раздробленности в Калмыцком ханстве владельцы восточных улусов во главе с Дорджи Назаровым сумели оказать вооруженный отпор противнику. Положение калмыцкого владельца было весьма незавидным, если учесть, что, с одной стороны, ему противостояла довольно сильная «партия» Дондук-Омбо, а с другой стороны, на него оказывало сильное давление российское правительство в лице астраханского губернатора А. П. Волынского, желая, чтобы тот принял ханскую власть после смерти Аюки-хана. Вдобавок к этому Дорджи Назарову приходилось еще и самостоятельно удерживать восточный фронт против казахов и каракалпаков, не имея никакой поддержки ни от других крупных владельцев, ни от российской армии.

Как справедливо отмечает Ж. Б. Кундакбаева, из-за недостатка средств и сил Россия мало вмешивалась в отношения степных народов, больше наблюдала, собирала информацию и декларировала о подданстве калмыков [Кундакбаева 2005: 198-199]. А. П. Волынский выступал как транслятор имперских идей: калмыки как подданные находятся под нашей охраной и обязательно получат помощь в случае внешней угрозы. Так, астраханский губернатор в одной из служебных записок приводит аргумент, почему он должен был откликнуться на призыв о помощи Дорджи Назарова: «И тамо их при таком случае надобно охранять или хуже тому, хотя один вид сделать. Дабы они, калмыки, во всяких случаях на Высокую Е. И. милость крепче были, благонадежны. А без того, они могут быть весьма

\section{Источники}

НА РК - Национальный архив Республики Калмыкия.

\section{Литература}

Батмаев 1993 - Батмаев М. М. Калмыки в XVII-XVIII веках. События, люди, быт: в 2-х книгах. Элиста: Калмкнигоиздат, 1993. $381 \mathrm{c}$.

Бакунин 1995 - Бакунин В. М. Описание калмыцких народов, а особливо из них торго- безнадежны и не будут иметь охоту по Высокой Е. И. В. протекцией держаться. Сверх того, ежели нужда призовет, требовать от них куда войск их, они смогут сами в том, таким же образом поступать, как с ними ныне поступлено будет. А принудить их будет невозможно» (цит. по: [Кундакбаева 2005: 198]).

Можно также согласиться с утверждением Л. А. Боброва, который считает, что Узенинское сражение имело важные военно-политические последствия, так как новая калмыцкая тактика в борьбе с казахами и каракалпаками, основанная на использовании одновременно конницы и мобильной артиллерии, показала свою эффективность и в дальнейшем активно использовалась калмыками. Победа даже над таким небольшим отрядом серьезно нанес ущерб военному потенциалу казахско-каракалпакского войска и наглядно показал, что захват калмыцких земель, даже в условиях отсутствия политического единства среди калмыцкой знати, является весьма нелегким делом [Бобров 2013: 15].

Вместе с тем этот небольшой локальный успех волжских калмыков не мог остановить дальнейшую экспансию казахов в восточном направлении. Возобновившееся наступление джунгарских войск в 1725 г. заставило казахских правителей искать пути возможного отступления в степи Северного Прикаспия и по возможности выстраивать отношения с калмыками на договорной основе. Однако отсутствие политического единства в Калмыцком ханстве делало его достаточно уязвимым ко внешней агрессии соседних кочевых народов и не способствовало укреплению калмыцко-казахских отношений. утского, и поступков их ханов и владельцев. 2-е изд. Элиста: Калм. кн. изд-во, 1995. $153 \mathrm{c}$.

Бобров 2013 - Бобров Л. А. Узенинская битва (1724 г.): предпосылки, ход, результаты // Научный Татарстан. 2013. № 2. С. 5-17. Болдырева 2017 - Болдырева О. Н. Пробле- 
ма взаимоотношений казахов и калмыков во II четверти XVIII в. // Каспийский регион: политика, экономика, культура. 2017. № 4(53). С. 24-28.

История Калмыкии 2009 - История Калмыкии с древнейших времен до наших дней. Элиста: ИД «Герел», 2009. Т. 1. 840 с.

Кундакбаева 2005 - Кундакбаева Ж. Б. «Знаком милости Е. И. В...». Россия и народы Северного Прикаспия в XVIII веке. М.: АИРО-XXI; СПб.: Дмитрий Буланин, 2005. $303 \mathrm{c}$.

История Казахстана 2005 - История Казахстана в русских источниках XVI-XX вв. Т. 2. Русские летописи и официальные материалы XVI - первой трети XVIII в. о народах Казахстана / сост. И. В. Ерофеева, науч. ред. Р. К. Нурмагамбетова. Алматы: Дайк-Пресс, 2005. $445 \mathrm{c}$.

Материалы 1935 - Материалы по истории каракалпаков (печатные и рукописные исторические известия о каракалпаках на русском языке) / ред. А. Н. Самойлович. Т. 7. М.; Л.: Изд-во АН СССР, 1935. 299 с.

\section{References}

Bakunin V. M. Description of Kalmyk Peoples, in Particular the Torghut People, and Deeds of Their Khans and Landlords. $2^{\text {nd }}$ ed. Elista: Kalmyk Book Publ., 1995. 153 p. (In Russ.)

Batmaev M. M. The Kalmyks, $17^{\text {th }}-18^{\text {th }}$ Centuries: Events, People, Household Life. In 2 vols. Elista: Kalmyk Book Publ., 1993. 381 p. (In Russ.)

Bobrov L. A. Uzeni battle (1724): background, course, results. Nauchnyi Tatarstan. 2013. No. 2. Pp. 5-17. (In Russ.)

Boldyreva O. N. The problem of relations of Kazakhs and Kalmyks in the II quarter of the XVIII century. The Caspian Region: Politics, Economics, Culture. 2017. No. 4(53). Pp. 24 28. (In Russ.)

Erofeeva I. V. (comp.), Nurmagambetova R. K. (ed.) History of Kazakhstan: Russian Chronicles, $16^{\text {th }}$ - $20^{\text {th }}$ Centuries. Vol. 2: Russian Manuscripts and Official Materials, $16^{\text {th }}-$ First Third of the $18^{\text {th }}$ Centuries. Peoples of Present-Day Kazakhstan. Almaty: Dayk-Press, 2005. 445 p. (In Russ.)

Kundakbaeva Zh. B. 'By the Mercy of His (Her) Imperial Majesty...': Russia and Peoples of the Northern Caspian in the $18^{\text {th }}$ Century. Moscow:
Пальмов 1929 - Пальмов Н. Н. Этюды по истории приволжских калмыков. Ч. 3-4. Астрахань: Издание Калм. Обл. Исп. Комитета, 1929. $391 \mathrm{c}$.

Сабитов 2014 - Сабитов Ж. М. Казахско-калмыцкие отношения в 1700-1715 годах // Средневековые тюрко-татарские государства. 2014. № 6. С. 122-126.

Тепкеев 2019 - Тепкеев В. Т. Калмыки, казахи и кубанские ногайцы в кампании 1738 г.: одна из малоизвестных страниц Русско-турецкой войны 1735-1739 гг. // Былые годы. 2019. № 4. C. 1459-1469.

Торопицын, Сусеева, Кундакбаева 2019 - Торопииьын И. В., Сусеева Д. А., Кундакбаева Ж. Б. Шаткий мир: казахско-калмыцкие отношения в начале 1740-х гг. // Вестник Калмыцкого университета. 2019. № 4(44). C. 63-68.

Цюрюмов 2009 - Цюрюмов А. В. Калмыцко-казахские отношения в первой трети XVIII века // К единству России: аспекты регионального и национального взаимодействия: мат. рег. науч.-практ. конф. Элиста: Джангар, 2009. С. 192-196.

AIRO-XXI; St. Petersburg: Dmitry Bulanin, 2005. 303 p. (In Russ.)

Maksimov K. N., Ochirova N. G. (eds.) History of Kalmykii: From Earliest Times to the Present Days. Elista: Gerel, 2009. Vol. 1. 840 p. (In Russ.)

Palmov N. N. The Volga Kalmyks: Historical Essays. Parts 3-4. Astrakhan: Kalmyk Oblast Executive Committee, 1929. 391 p. (In Russ.)

Sabitov Zh. M. Kazakh-Kalmyk relations in the 1700-1715 years. Medieval Turkic-Tatar States. 2014. No. 6. Pp. 122-126. (In Russ.)

Samoylovich A. N. (ed.) Materials on Karakalpak History: Russian-Language Printed and Manuscript Historical Messages about Karakalpaks. Vol. 7. Moscow; Leningrad: USSR Academy of Sciences, 1935. 299 p. (In Russ.)

Tepkeev V. T. Kalmyks, Kazakhs and Kuban Nogais in the campaign of 1738: one of the little-known pages of the Russian-Turkish War of 1735-1739. Bylye Gody. 2019. No. 4. Pp. 1459-1469. (In Russ.)

Toropitsyn I. V., Suseeva D. A., Kundakbaeva Zh. B. Shaky world: Kazakh-Kalmyk relations in the beginning of the 1740s. Bulletin of Kalmyk University. 2019. No. 4(44). Pp. 63-68. (In Russ.) 
Oriental Studies. 2021. Vol. 14. Iss. 1

Tsyuryumov A. V. Kalmyk-Kazakh relations, 1700s - 1730s. In: Towards United Russia. Aspects of

Regional and Ethnic Interaction. Conference
Proceedings. Elista: Dzhangar, 2009. Pp. $192-$ 196. (In Russ.) 